\title{
Ekonomiczne uwarunkowania funkcjonowania systemów IT w przedsiębiorstwach - perspektywa wdrożeniowa
}

\author{
Dr Marcin Szplit iD \\ Uniwersytet Jana Kochanowskiego w Kielcach \\ Wydział Prawa i Nauk Społecznych \\ Katedra Zarządzania
}

\section{Wprowadzenie}

Wzrastająca dynamika otoczenia wymusza dostosowanie systemów zarządzania do zmian zachodzących w środowisku organizacji. Przejawem procesów dostosowawczych jest zastosowanie systemów informatycznych do wspomagania zarządzania przedsiębiorstwem.

Celem opracowania jest prezentacja wyników badań pilotażowych identyfikujących uwarunkowania sytuacyjno-organizacyjne skuteczności wdrażania systemów informatycznych poprzez identyfikację kluczowych czynników sukcesu oraz efektów wdrażania tego podejścia.

Prezentowane wyniki są częścią szerszego projektu badawczego, zmierzającego do identyfikacji uwarunkowań skuteczności wdrażania systemów informatycznych do zarządzania przedsiębiorstwem poprzez:

- analizę metodyki wdrożeń;

- identyfikację uwarunkowań instytucjonalnych;

- identyfikację uwarunkowań sytuacyjno-organizacyjnych.

\section{Metodyka postępowania badawczego}

Dla potrzeb badawczych określono zbiór zmiennych szczegółowych, charakteryzujących w sposób skwantyfikowany wymiary różnych potencjalnych uwarunkowań sytuacyjno-organizacyjnych skuteczności wdrażania systemów IT, wspomagających zarządzanie przedsiębiorstwem. W toku postępowania badawczego ze zbioru 
potencjalnych uwarunkowań wyodrębnione zostały uwarunkowania rzeczywiste, czyli te, które wpływają na skuteczność wdrożenia IT.

Identyfikację rzeczywistych uwarunkowań skuteczności wdrażania podejścia procesowego do zarządzania przedsiębiorstwem przeprowadzono na podstawie odpowiedzi do ankiety skierowanej do jednostek gospodarczych zarejestrowanych w ramach klastra FutureHub działającego przy Kieleckim Parku Technologicznym, według stanu na koniec 2018 roku.

Wypełnienie ankiety polegało na zaznaczeniu jednego lub kilku proponowanych wariantów odpowiedzi, ewentualnie, w niektórych przypadkach, na udzieleniu odpowiedzi opisowej.

\section{Uwarunkowania wdrożenia systemu IT w przedsiębiorstwie}

Zakup oprogramowania wspomagającego zarządzanie przedsiębiorstwem to nic innego jak inwestycja, która na początku powinna zostać dobrze zaplanowana. W tym celu wybiera się tzw. wskaźniki KPI (Key Performance Indicators), czyli kluczowe wyznaczniki efektywności. Każda firma przed podjęciem decyzji o wyborze dostawcy powinna przeprowadzić szczegółową analizę potrzeb i na jej podstawie dobrać odpowiedni zestaw KPI. Wybór odpowiednich wskaźników efektywności zależy od kilku kluczowych aspektów, takich jak¹:

- wielkość firmy;

- branża, w jakiej działa przedsiębiorstwo;

- strategia biznesowa firmy na najbliższe lata;

- kluczowe problemy, z jakimi zmaga się firma;

- poziom zaawansowania technologicznego.

Analiza kosztów wdrożenia to ważny etap, który wymaga przeanalizowania i porównania ofert co najmniej kilku dostawców. Koszt samego wdrożenia systemu to tylko jedna z wielu składowych pełnej wyceny. Składając zapytanie ofertowe, przedsiębiorca powinien więc zadać kilka dodatkowych pytań:

- „Ile wynoszą opłaty za bieżącą obsługę systemu po wdrożeniu?”;

- „Jaki jest średni koszt aktualizacji oprogramowania do najnowszej wersji?”;

- „Czy system posiada zestaw dodatkowo płatnych funkcjonalności?”;

- „Czy za dostosowywanie oprogramowania do najnowszych wymogów prawnych trzeba dodatkowo płacić?";

1 Opracowanie własne na podstawie P. Lech, Metodyka ekonomicznej oceny przedsięwzięć informatycznych wspomagajacych zarządzanie organizacja, Wydawnictwo Uniwersytetu Gdańskiego, Gdańsk 2007, s. 112. 
- „Czy pojawią się dodatkowe koszty związane z obsługą klienta?”;

- „Czy dostawca jest wiarygodny i ma doświadczenie, które pozwoli mu utrzymać się na rynku nawet w dobie ewentualnego kryzysu?”.

Odpowiedzi dostawców na powyższe pytania pomogą oszacować koszty związane z nowym systemem, które firma miałaby ponosić przez najbliższe lata.

Ocena związku przedsięwzięcia informatycznego ze strategią organizacji oraz ustalenie stopnia realizacji jego celów określa wpływ tego przedsięwzięcia na tworzenie wartości organizacji w długim okresie. Drugim elementem systemu oceny jest pomiar efektywności tego przedsięwzięcia, rozumianej jako stosunek cenności wyników użytecznych do cenności kosztów. Mając na uwadze klasyfikację korzyści i kosztów, należy stwierdzić, że ocena efektywności przedsięwzięcia informatycznego może dotyczyć kilku poziomów, w zależności od typów korzyści i kosztów, które zostaną do niej włączone. Ze względu na kryterium związku pomiędzy przedsięwzięciem informatycznym a wynikami ekonomicznymi organizacji efektywność tego przedsięwzięcia można mierzyć na poziomie:

- bezpośrednich korzyści i kosztów;

- pełnych korzyści i kosztów (zarówno bezpośrednich, jak i pośrednich).

Ze względu na możliwość finansowego wyrażenia efektów efektywność można natomiast oceniać na poziomie:

- finansowych korzyści i kosztów;

- pełnych korzyści i kosztów (zarówno finansowych, jak i niefinansowych).

Przy pomiarze efektywności na poziomie drugim zaistnieje konieczność sprowadzenia do wspólnego mianownika wszystkich korzyści i kosztów, finansowych do niefinansowych i niefinansowych między sobą.

Pomiędzy elementami dwóch przedstawionych powyżej klasyfikacji zachodzą kombinacje, których analiza prowadzi do wniosku, że ocena efektywności może odbywać się na następujących poziomach:

- bezpośrednich finansowych korzyści i kosztów;

- bezpośrednich pełnych (finansowych i niefinansowych) korzyści i kosztów;

- pełnych (bezpośrednich i pośrednich) finansowych korzyści i kosztów;

- pełnych korzyści i kosztów.

Dodatkowo należy pamiętać o kolejnym kryterium podziału korzyści i kosztów, jakim jest ich mierzalność. Niemierzalne korzyści i koszty mogą być jedynie wymienione i opisane, a w ten sposób mogą być ujęte jako dodatek do wyrażonej za pomocą ilorazu efektywności korzyści i kosztów mierzalnych².

2 Opracowanie własne na podstawie J. Kisielnicki, H. Sroka, Systemy informacyjne biznesu. Metody projektowania i wdrażania systemów, Agencja Wydawnicza „Placet”, Warszawa 2001, s. 272. 


\section{Wyniki badań pilotażowych}

Badania udało się przeprowadzić w jedenastu przedsiębiorstwach, które są zaangażowane w proces wdrożenia systemów IT. Charakter badań powoduje, że należy określić je jako badania eksploracyjne. Ogólnym celem badania eksploracyjnego jest uzyskanie rozpoznania zagadnienia. W tego typu badaniach wykonujący je kieruje się zazwyczaj wyjściową hipotezą. Hipoteza jest wypowiedzią, która określa sposób powiązania dwóch lub większej liczby poddających się pomiarowi zmiennych ${ }^{3}$. W przypadku badań zrealizowanych na potrzeby niniejszej pracy przyjęto następujące hipotezy:

- Wdrożenie systemu wspomagania informacyjnego jest wynikiem realizacji strategii przedsiębiorstwa.

- Wdrożone systemy IT wykorzystywane są w stopniu niezadowalającym dla kierownictwa przedsiębiorstw.

Jedno z pierwszych pytań dotyczyło togo, w jakim stopniu kierownictwo przedsiębiorstwa, w którym był wdrażany system IT, było zaangażowane w proces wdrożenia.

Tabela 1. Związek pomiędzy zaangażowaniem kierownictwa przedsiębiorstwa a oceną działania systemu IT

\begin{tabular}{|c|c|c|c|}
\hline Stopień zadowolenia & Zaangażowanie kierownictwa & Tak & Nie \\
\hline 1 & & 0 & 9 \\
\hline 2 & & 0 & 4 \\
\hline 3 & & 0 & 6 \\
\hline 4 & & 5 & 5 \\
\hline 5 & & 3 & 0 \\
\hline Średnia & & 4,1 & 2,5 \\
\hline Odchylenie standardowe & & 0,6 & 1,4 \\
\hline
\end{tabular}

Źródło: opracowanie własne.

Sprawdzenie związku pomiędzy zaangażowaniem kierownictwa a stopniem zadowolenia zostało wykonane za pomocą testu U Manna-Whitneya. Obliczenia pozwoliły ustalić, że na poziomie istotności $p<0,01$ stopień zadowolenia jest istotnie wyższy w przypadku firm, w których kierownictwo zaangażowało się w projekt IT (wartość statystyku U wyniosła 12,5).

Następnym pytaniem badawczym było odkrycie związków pomiędzy strategią przedsiębiorstwa a wdrożeniem systemu IT oraz wzajemnym wpływem przyjętej

3 G.A. Churchill, Badania marketingowe. Podstawy metodologiczne, Wydawnictwo Naukowe PWN, Warszawa 2002, s. 157. 
strategii na sukces projektu IT. Posłużyły do tego pytania dotyczące pisemnej strategii dotyczącej IT oraz wpływu wdrożenia systemu IT na ewentualne zmiany w strategii. Według odpowiedzi na jedno z pytań kwestionariusza tylko $40 \%$ przedsiębiorstw sformułowało pisemną strategię dotyczącą IT. Natomiast 100\% badanych firm twierdziło, że strategia wdrożenia IT wynika z ogólnej strategii rozwoju całej organizacji. Odpowiedź na pytanie o wpływ wdrożenia i działania systemu IT na strategię na ogół była negatywna. Swojej strategii pod wpływem projektu nie zmieniało $82 \%$ przedsiębiorstw. Interpretując te wyniki, można powiedzieć, że świadczą one o niewielkim powiązaniu pomiędzy strategią przedsiębiorstwa a działaniem systemu IT. Nikły wpływ wdrożenia strategii IT na bieżącą strategię ogólną całej firmy dowodzi traktowania systemu jako kolejnego narzędzia, a nie jako metody zmiany modelu biznesu.

Tabela 2 pokazuje zależność pomiędzy sformułowaniem pisemnej strategii IT a zadowoleniem $\mathrm{z}$ wdrożenia oraz osiągniętych celów działania systemu IT. Pomiar ma charakter jakościowy (nie odnosi się do tzw. twardych czynników, jak np. $R O I)$ i wykazuje, że nie ma istotnych różnic pomiędzy firmami, które sformułowały pisemną strategię dotyczącą IT, a tymi, które tego nie uczyniły. Można natomiast zauważyć niewielką poprawę zadowolenia z osiągniętych wyników wśród tych firm, które zmodyfikowały swoją strategię ogólną w odpowiedzi na wyzwania ze strony systemu IT. Jest to szczególnie znamienne, jeśli weźmie się pod uwagę fakt, że to właśnie zmiany organizacyjne powodują naruszenie równowagi sił wewnątrz organizacji i konflikty kompetencyjne wewnątrz jej struktury. Tabela 2 ilustruje wpływ czynników strategicznych na poziom zadowolenia z projektu IT oraz analizę statystyczną związków ustaloną za pomocą korelacji.

Tabela 2. Czynniki strategiczne a poziom zadowolenia z projektu IT

\begin{tabular}{|l|c|c|c|c|}
\cline { 2 - 5 } \multicolumn{1}{c|}{} & \multicolumn{2}{c|}{$\begin{array}{c}\text { Pisemna strategia } \\
\text { IT }\end{array}$} & \multicolumn{2}{c|}{$\begin{array}{c}\text { Zmiany w strategii przedsiębiorstwa } \\
\text { spowodowane przez wdrożenie IT }\end{array}$} \\
\cline { 2 - 5 } \multicolumn{1}{c|}{} & Tak & Nie & Tak & Nie \\
\hline Zadowolenie z wdrożenia & 2,9 & 2,7 & 3,5 & 2,4 \\
\hline Zadowolenie z osiągniętych celów & 3,4 & 2,4 & 4,2 & 2,5 \\
\hline
\end{tabular}

Źródło: opracowanie własne.

W celu porównania uzyskanych wyników zastosowano test t-Studenta istotności dwóch średnich dla 30 stopni swobody i poziomu $\alpha=0,05$. Uzyskane wyniki obliczeń zebrano w tabeli 3. 
Tabela 3. Istotność różnic średnich

\begin{tabular}{|c|c|c|c|c|c|c|}
\hline \multicolumn{4}{|c|}{ Zadowolenie } & $\begin{array}{c}\text { Średnia } \\
\text { z ocen }\end{array}$ & $\begin{array}{c}\text { Wartość } \\
\text { statystyki t }\end{array}$ & $\begin{array}{c}\text { Wartość } \\
\text { krytyczna }\end{array}$ \\
\hline \multirow{8}{*}{$\begin{array}{l}\text { Zadowolenie } \\
\text { z wdrożenia }\end{array}$} & \multirow{4}{*}{$\begin{array}{l}\text { Założenie } \\
\text { o równości } \\
\text { wariancji }\end{array}$} & \multirow{2}{*}{ Pisemna strategia } & Tak & 2,9 & \multirow[t]{2}{*}{0,364} & \multirow[t]{2}{*}{2,042} \\
\hline & & & Nie & 2,7 & & \\
\hline & & \multirow{2}{*}{ Zmiany w strategii } & Tak & 3,5 & \multirow[t]{2}{*}{1,350} & \multirow[t]{2}{*}{2,042} \\
\hline & & & Nie & 2,4 & & \\
\hline & \multirow{4}{*}{$\begin{array}{l}\text { Założenie } \\
\text { o różności } \\
\text { wariancji }\end{array}$} & \multirow{2}{*}{ Pisemna strategia } & Tak & 2,9 & \multirow[t]{2}{*}{0,345} & \multirow[t]{2}{*}{2,079} \\
\hline & & & Nie & 2,7 & & \\
\hline & & \multirow{2}{*}{ Zmiany w strategii } & Tak & 3,5 & \multirow[t]{2}{*}{1,354} & \multirow[t]{2}{*}{2,306} \\
\hline & & & Nie & 2,4 & & \\
\hline \multirow{8}{*}{$\begin{array}{l}\text { Zadowolenie } \\
\text { z osiągniętych } \\
\text { celów }\end{array}$} & \multirow{4}{*}{$\begin{array}{l}\text { Założenie } \\
\text { o równości } \\
\text { wariancji }\end{array}$} & \multirow{2}{*}{ Pisemna strategia } & Tak & 3,4 & \multirow[t]{2}{*}{2,001} & \multirow[t]{2}{*}{2,042} \\
\hline & & & Nie & 2,4 & & \\
\hline & & \multirow{2}{*}{ Zmiany w strategii } & Tak & 4,2 & \multirow[t]{2}{*}{2,930} & \multirow[t]{2}{*}{2,042} \\
\hline & & & Nie & 2,5 & & \\
\hline & \multirow{4}{*}{$\begin{array}{l}\text { Założenie } \\
\text { o różności } \\
\text { wariancji }\end{array}$} & \multirow{2}{*}{ Pisemna strategia } & Tak & 3,4 & \multirow[t]{2}{*}{1,922} & \multirow[t]{2}{*}{2,074} \\
\hline & & & Nie & 2,4 & & \\
\hline & & \multirow{2}{*}{ Zmiany w strategii } & Tak & 4,2 & \multirow[t]{2}{*}{4,129} & \multirow[t]{2}{*}{2,160} \\
\hline & & & Nie & 2,5 & & \\
\hline
\end{tabular}

Źródło: opracowanie własne.

Jedynie w przypadku analizowania istotności wystąpienia zmian w strategii przedsiębiorstwa i osiągniętego poziomu zadowolenia ze zrealizowanych celów otrzymano wartość $t$, która jest większa od wartości krytycznej. W związku z tym należy przyjąć hipotezę o istotnej różnicy w poziomach zadowolenia z osiągniętych celów w zależności od wystąpienia zmian organizacyjnych w przedsiębiorstwie. Pozostałe testy wykazały, że wartość statystyki jest niższa od wartości krytycznej testu, co oznacza, że zmierzone różnice w poziomach zadowolenia nie są statystycznie istotne. Testy przeprowadzono przy założeniu zarówno równej, jak i nierównej wariancji, uzyskując bardzo zbliżone wyniki.

\section{Podsumowanie}

Wynik analiz statystycznych potwierdził istnienie związku pomiędzy wystąpieniem zmian w strategii ogólnej przedsiębiorstwa a wdrożeniem systemu IT. Wystąpienie takich zmian w istotny sposób wpłynęło na średni poziom zadowolenia z osiągniętych celów wdrożenia systemu IT. Pozostałe różnice w średnich poziomach zadowolenia okazały się statystycznie nieistotne. Należy zwrócić uwagę na fakt, że wystąpienie zmian organizacyjnych wiążę się z dość znacznymi zmiana$\mathrm{mi}$. Jeśli kierownictwo przedsiębiorstwa decyduje się na istotną ingerencję w strukturę, oznacza to poważne podejście do problematyki IT, a nie traktowanie wdrożenia systemu jako kolejnego systemu informatycznego. Lektura wielu przypadków 
opisujących nieudane wdrożenia systemów IT w przedsiębiorstwach wskazuje jako najważniejszą przyczynę porażek brak powiązania ze strategią przedsiębiorstwa. Przeprowadzone badania nie pozwalają na poparcie takiego wniosku, ale uwidaczniają, że większość menedżerów badanych firm nie zauważa związku pomiędzy czynnikami strategicznymi a oceną projektu IT. Jedynym czynnikiem, którego wystąpienie ma związek z oceną funkcjonowania systemu IT, jest wystąpienie zmian w obrębie jego struktury.

Ograniczenie się wyłącznie do zmian w strukturze może okazać się jednak błędem. Należy zauważyć, że pisemne sformułowanie strategii wobec systemu IT nadaje celom wdrożenia bardziej formalny charakter, a także ułatwia kontrolę na poszczególnych etapach uruchamiania systemu. Sformułowanie pisemnej strategii dotyczącej wdrożenia jest uzasadnione zwłaszcza w powiązaniu z realistycznie opracowanym harmonogramem prac nad systemem. Taka strategia staję się narzędziem kontroli strategicznej.

Bibliografia

Churchill G.A., Badania marketingowe. Podstawy metodologiczne, Wydawnictwo Naukowe PWN, Warszawa 2002.

Kisielnicki J., Sroka H., Systemy informacyjne biznesu. Metody projektowania i wdrażania systemów, Agencja Wydawnicza „Placet”, Warszawa 2001.

Lech P., Metodyka ekonomicznej oceny przedsięwzięć informatycznych wspomagajacych zarzqdzanie organizacja, Wydawnictwo Uniwersytetu Gdańskiego, Gdańsk 2007.

\section{Streszczenie}

W rozdziale przedstawiono wyniki badań nad systemami IT i ich związkami ze strategią przedsiębiorstw. We wstępie nakreślono zasadnicze powody, dla których przedsiębiorstwa wdrażają systemy IT wspomagające zarządzanie. W dalszej części autor zaprezentował wyniki badań przeprowadzonych wśród firm zajmujących się sprzedażą i wdrożeniami systemów IT, skupionych w klastrze FutureHub, działającym w ramach Kieleckiego Parku Technologicznego. W części empirycznej wykorzystano metody analizy statystycznej dla wykazania związku sukcesu wdrożenia systemu IT z przyjętą strategią ogólną organizacji.

Słowa kluczowe: systemy komputerowe, strategia przedsiębiorstwa, systemy IT, wdrożenia systemów IT 
Economic conditions for operation of IT systems in enterprises

- implementation perspective

\section{Abstract}

The article presents the results of research on IT systems and their relationships with enterprise strategy. The introduction outlines the main reasons why companies implement management support IT systems. In the next part, the author presents the results of the research conducted among companies involved in the sale and implementation of IT systems, concentrated in the FutureHub cluster, operating within the Kielce Technology Park. In the empirical part, methods of statistical analysis have been used to demonstrate the relationship between the success of IT system implementation and the adopted general strategy of the organization.

Keywords: computer systems, enterprise strategy, IT systems, IT systems implementation 